\title{
Predykcja upadłości przedsiębiorstw - przykład Monnari Trade S.A.
}

Patrycja Melon*

\section{Streszczenie}

W artykule przedstawiono zjawisko upadłości oraz bankructwa przedsiębiorstw. Za bankruta jest uznawane przedsiębiorstwo, które nie posiada wystarczającej wartości środków finansowych umożliwiających spłatę powstałych zobowiązań. W literaturze przedmiotu upatruje się wielu przyczyn tego zjawiska. Jedną z nich jest pogorszenie sytuacji finansowej podmiotu gospodarczego, co skutkuje brakiem wypłacalności.

Pojawiające się symptomy świadczące o pogarszającej się sytuacji przedsiębiorstwa należy analizować. Wczesne dostrzeżenie niepokojących sygnałów oraz wprowadzenie działań naprawczych może zapobiec upadłości przedsiębiorstwa. W oparciu o wieloletnie badania stworzono specjalne narzędzia określające upadłość danego podmiotu - modele predykcji upadłości. Celem artykułu jest weryfikacja skuteczności wybranych polskich modeli predykcji upadłości przedsiębiorstwa w procesie prognozowania upadłości spółki Monnari Trade S.A.

Analizy tej dokonano na podstawie danych pozyskanych z bazy danych EMIS - Standard MSSF dla przedsiębiorstw niefinansowych. Wartości funkcji zostały obliczone za pomocą programu MS Excel. Hipoteza badawcza brzmi: modele prognozowania upadłości przedsiębiorstwa Hadasik, Hołdy, Prusaka, Hamrola, Czajki i Piechockiego służą odpowiednio wczesnemu zaalarmowaniu o zagrożeniu upadłością badanego podmiotu gospodarczego. Na podstawie uzyskanych wartości modeli wskazano, czy (i na ile) są one skuteczne.

Słowa kluczowe: predykcja bankructwa, przedsiębiorstwo, modele dyskryminacyjne

JEL: F37, P12

* Patrycja Melon - studentka, Uniwersytet Łódzki, Wydział Ekonomiczno-Socjologiczny, Kierunek studiów: Finanse i Biznes Międzynarodowy, patrycja.melon@edu.uni.lodz.pl.

(C) by the author, licensee Łódź University - Łódź University Press, Łódź, Poland. This article is an open access article distributed under the terms and conditions of the Creative Commons Attribution license CC BY-NC-ND 4.0 (https://creativecommons.org/licenses/by-nc-nd/4.0/) 


\section{Wstęp}

Przedsiębiorstwa są podmiotami gospodarczymi prowadzącymi działalność produkcyjną, handlową bądź usługową, które posiadają odrębność ekonomiczną, prawną oraz organizacyjną. Głównym celem ich działalności jest maksymalizacja majątku właścicieli podmiotu, który został wygenerowany dzięki zaangażowaniu posiadanych zasobów (Buczyńska 2007, s. 189-190). Należy zauważyć, iż głównym celem przedsiębiorstwa jest maksymalizacja wartości rynkowej, która polega na wzroście udziałów lub wartości akcji (Sudoł 2006, s. 68-69). To istotne dla akcjonariuszy oraz pracowników podmiotu gospodarczego - dzięki temu przedsiębiorstwo może się rozwijać, zwłaszcza przy dużej konkurencji oraz dynamicznej gospodarce. W ostatnich dwóch dekadach obserwuje się zwiększoną liczbę nowych przedsiębiorstw w Polsce oraz na obszarze Unii Europejskiej (Zakrzewski i Chaber 2017, s. 14). W 2015 r. w Polsce założono blisko 250 tysięcy nowych przedsiębiorstw, a z rejestru gospodarczego wykreślono 239 tysięcy podmiotów (PARP 2017, s. 14). Natomiast we Włoszech liczba zlikwidowanych w 2015 r. przedsiębiorstw była wyższa niż liczba nowo powstałych podmiotów - wyrejestrowano 340 tysięcy jednostek, nowych zaś założono jedynie 279 tysięcy. Włochy są przykładem kraju, w którym w 2015 r. więcej podmiotów zostało zlikwidowanych niż zarejestrowanych (PARP 2017, s. 14). W przypadku Polski należy zwrócić uwagę na nagły wzrost liczby upadłości przedsiębiorstw w latach 2017-2018. W tym okresie ponad 332 tysiące podmiotów gospodarczych zostało wyrejestrowanych (PARP 2020, s. 11). Zaobserwowane zmiany w liczbie ogłoszonych upadłości przedsiębiorstw wskazują na wagę i aktualność wybranej problematyki badawczej.

Celem artykułu jest weryfikacja skuteczności wybranych polskich modeli prognozowania upadłości przedsiębiorstwa w procesie predykcji upadłości spółki Monnari Trade S.A. Kryzys na rynku kredytów sub-prime doprowadził Monnari Trade S.A. do upadłości układowej we wrześniu 2010 r. W oparciu o przedstawione modele można wskazać, czy zarząd Monnari Trade S.A. był w stanie odpowiednio wcześnie zauważyć pogarszającą się sytuację finansową. Hipoteza badawcza brzmi: modele predykcji upadłości przedsiębiorstw autorstwa Hadasik, Hołdy, Prusaka, Hamrola, Czajki i Piechockiego skutecznie informują o zagrożeniu upadłością badanego podmiotu gospodarczego.

$\mathrm{W}$ artykule wykorzystano modele predykcji upadłości przedsiębiorstw do oceny sytuacji spółki Monnari Trade S.A. Przedsiębiorstwo to zostało wybrane do badań, ponieważ mimo złej sytuacji finansowej spółki, dzięki natychmiastowej reakcji jej zarządu oraz inwestorów, Monnari Trade S.A. nie upadła. Dane służące do analizy modeli predykcji upadłości Monnari Trade S.A. pozyskano z bazy danych EMIS - Standard MSSF dla przedsiębiorstw niefinansowych, a następnie wyliczono wartości funkcji za pomocą programu MS Excel. Okresem 
badawczym, dla którego przeprowadzono obliczenia, są lata 2008-2014. Mają one na celu przedstawić sytuację finansową podmiotu gospodarczego w czasie kryzysu finansowego w momencie wszczęcia postępowania upadłościowego oraz po opanowaniu kryzysu w spółce.

Opracowanie składa się z trzech części. W pierwszej części scharakteryzowano pojęcie bankructwa i upadłości przedsiębiorstw, a także opisano przyczyny oraz proces tego zjawiska. W części drugiej przedstawiono polskie modele predykcji upadłości przedsiębiorstw. W części trzeciej dokonano analizy sytuacji finansowo-ekonomicznej spółki Monnari Trade S.A. za pomocą wybranych polskich modeli predykcji upadłości przedsiębiorstw.

\section{Bankructwo i upadłość przedsiębiorstw}

Jak podkreśla Mączyńska i Zawadzki, na przestrzeni ostatnich dwóch dekad coraz częściej mamy do czynienia ze zjawiskiem bankructwa oraz upadłości przedsiębiorstw. Przedsiębiorstwa niedziałające efektywnie upadają, co doprowadza do stopniowego oczyszczania gospodarki ze zbyt dużej liczby podmiotów funkcjonujących na danych rynkach (Mączyńska i Zawadzki 2006, s. 205).

Za przedsiębiorstwo, które zbankrutowało (z ekonomicznego punktu widzenia) uznaje się podmiot, który nie jest w stanie prowadzić samodzielnie działalności gospodarczej bez udzielonej mu pomocy z zewnątrz. Mimo iż przedsiębiorstwo działa na rynku, to nie spłaca swoich zobowiązań w określonych terminach (Bauer 2010). Zazwyczaj pomoc z zewnątrz polega na wydłużeniu terminu spłaty zobowiązania bądź umorzeniu spłaty długu, dokapitalizowaniu przedsiębiorstwa przez podmioty z zewnątrz czy pomocy państwa $\mathrm{w}$ formie udzielenia gwarancji (Korol i Prusak 2014, s. 12). Najczęściej przyczyną bankructwa są dwa przypadki. Pierwszym z nich jest pogorszenie sytuacji finansowej jednostki, czego skutkiem jest niewypłacalność oznaczająca sytuację, w której wartość rynkowa danego przedsiębiorstwa jest mniejsza niż wartość powstałych zobowiązań. Kolejną przesłanką jest brak płynności finansowej, czyli zaległości w spłacaniu powstałych zobowiązań (Altman 1968).

Upadłość przedsiębiorstwa ma natomiast inne znaczenie, lecz rozumiana jest w kontekście bankructwa. Jak wskazują Korol i Prusak „nie każde bankructwo ekonomiczne musi (...) oznaczać upadłość w rozumieniu prawa, lecz prawie każda upadłość w sensie prawnym oznacza bankructwo ekonomiczne" (Korol i Prusak 2014, s. 12). Wyjątkiem jest sytuacja, gdy wprowadzenie postępowania upadłościowego jest wcześniej zamierzone.

W aspekcie prawnym upadłość jest definiowana jako rodzaj przymusu zaspokojenia zaległych wierzytelności. Dopuszczalne jest to w sytuacji, gdy dłużnik nie jest wypłacalny (Korol i Prusak 2014, s. 12-13). Według prawa pojęcie upadłości 
jest związane z postępowaniem sądowym, które zawiera określone procedury m. in. proces upadłościowy czy ogłoszenie upadłości jednostki gospodarczej.

Na podstawie polskiego prawa upadłościowego i naprawczego (Prawo upadłościowe i naprawcze z 28.03.2003, Dz.U. 2003 nr 60 poz. 535), które obowiązuje od 1 października 2003 r. przesłankami ogłoszenia upadłości są:

- Dłużnik posiada odpowiednią wielkość majątku wystarczającego na poniesienie kosztów przeprowadzenia postępowania upadłościowego. Ważne jest, aby podmiot ten posiadał nieobciążony hipoteką majątek pozwalający na uregulowanie kosztów postępowania (art. 13 p.u. i n.);

- Dłużnik nie jest jednostką wypłacalną, co według art. 11 p.u. i n. oznacza brak możliwości spłaty powstałych zobowiązań. W celu zbadania przesłanki upadłości należy porównać wartość majątku należącą do dłużnika oraz wartość powstałych długów. Jeżeli wartość zobowiązań dłużnika jest wyższa niż wielkość posiadanego przez niego majątku, to przesłanka ogłoszenia upadłości jest spełniona. W skład wartości zobowiązań nie jest wliczana wartość kapitału zapasowego, zakładowego oraz rezerwowego (na początku spłacane są obce zobowiązania).

Ogłoszenie upadłości jest długotrwałym procesem. Przedsiębiorstwo, które taką upadłość ma ogłosić, powinno zostać poddane dokładnej analizie. W literaturze przedmiotu istnieją trzy normy dotyczące wszczęcia postępowania upadłościowego przedsiębiorstwa (Balina i Bąk 2016, s. 74):

- Normy materialno-prawne: opisują skutki cywilno-prawne, finansowe oraz przesłanki działań. Należy wyszczególnić, a następnie przekazać syndykowi całość majątku po ogłoszeniu upadłości z likwidacją majątku (Prawo upadłościowe i naprawcze, Ustawa z dnia 28 lutego 2003 r., Dz.U. 2003 nr 60 poz. 535, art. 53).

- Normy proceduralne: przedstawiają zasady postępowania w sytuacji, gdy ogłoszenie upadłości należy wskazać do publicznej wiadomości. Następuje to poprzez obwieszczenie w Monitorze Sądowym oraz Gospodarczym (Prawo upadłościowe i naprawcze, Ustawa z dnia 28 lutego 2003 r., Dz.U. 2003 nr 60 poz. 535, art. 57).

- Normy karne: określają sankcje karne, które są nakładane w przypadku nieprzestrzegania wskazanych norm prawnych. Jeśli dłużnik, bądź osoba prawna będąca reprezentantem dłużnika, nie poda wszelkich danych we wniosku o ogłoszenie upadłości bądź oświadczeniu o wszczęciu postępowania upadłościowego, podlega karze pozbawienia wolności do 5 lat (Prawo upadłościowe i naprawcze, Ustawa z dnia 28 lutego 2003 r., Dz.U. $2003 \mathrm{nr} 60$ poz. 535, art. 522, art. 53).

Dłużnik bądź osoba reprezentująca dłużnika jest zobowiązana złożyć wniosek dotyczący wszczęcia postępowania upadłościowego w terminie do 14 dni po pojawieniu się przesłanek wskazujących na niewypłacalność podmiotu (Prawo 
upadłościowe i naprawcze, Ustawa z dnia 28 lutego 2003 r., Dz.U. 2003 nr 60 poz. 535, art. 21). W innym przypadku mogą wystąpić tzw. ,upadłości symulowane" polegające na pobraniu całego majątku z danej jednostki, a następnie ogłoszeniu upadłości. Takie zachowanie może doprowadzić do sytuacji, gdy nie będzie możliwe pokrycie wszelkich wierzytelności wobec kontrahentów danego przedsiębiorstwa (Prusak 2002, s. 45). Jednym z zadań upadłości przedsiębiorstw jest chronienie interesu publicznego, gdyż niewypłacalne podmioty mogą mieć negatywny wpływ m.in. na płynność finansową innych jednostek gospodarczych.

Jak podkreślają Abdali i Abbas zdarza się, że upadające przedsiębiorstwo nie jest w stanie wywiązać się z powstałych zobowiązań, nawet gdy zostało wydane orzeczenie sądowe. Najczęściej takie zobowiązania są spłacane poprzez reorganizację długów danego przedsiębiorstwa bądź sprzedaż (likwidację) posiadanych aktywów. Upadłość może się stać sposobem na uniknięcie spłaty części długów (Abdali i Abbas 2015, s. 156).

\section{Przyczyny upadłości przedsiębiorstw}

W literaturze przedmiotu wskazuje się wiele przyczyn upadłości przedsiębiorstw (Mączyńska i Zawadzki 2000). Podstawowymi przesłankami mogą być duża konkurencja rynkowa, toczące się postępowania sądowe, nieprawidłowe zarządzanie jednostką czy błędy popełnione w sferze operacyjnej. Mączyńska i Zawadzki podzielili przyczyny powstawania bankructwa na mikro- oraz makroekonomiczne. Wśród wskazanych przez nich przyczyn mikroekonomicznych znalazły się źle wybrana lokalizacja przedsiębiorstwa, zbyt mały rozmiar działalności gospodarczej, przestarzała technologia, brak odpowiednio wykwalifikowanych pracowników czy zła jakość produkowanych towarów. Istotne jest również posiadanie niewielkiej bazy kontrahentów. Do głównych przyczyn makroekonomicznych można zaliczyć globalizację rynków, wahające się kursy walutowe oraz nagłą zmianę struktury popytu (Mączyńska i Zawadzki 2000).

Zarządzający przedsiębiorstwem powinni dokładnie analizować jego sytuację ekonomiczno-finansową. Wszelkie symptomy, które mogą świadczyć o jej pogorszeniu, należy wnikliwie zbadać. Jeśli zagrożenie zostanie w porę zauważone, w przedsiębiorstwie można wdrożyć specjalistyczne programy naprawcze.

Istnieje podział sygnałów alarmujących o zagrożeniu. Pierwszego rodzaju symptomów należy szukać w sferze operacyjnej podmiotu, która jest silnie powiązana ze sferą podstawowej działalności przedsiębiorstwa. Do symptomów w sferze operacyjnej, w przypadku podziału działalności według rachunkowości, można zaliczyć takie czynniki jak zmniejszenie bazy klientów, stale zmniejszające się udziały sprzedaży na rynku czy brak rentownych projektów rozwojowych. Kolejne symptomy pojawiają się w sferze finansowej. Mogą one świadczyć 
o nadchodzącym kryzysie, gdy przedsiębiorstwo generuje mniejsze zyski lub rosnące straty netto. Ponadto alarmujące są coraz niższe wartości wskaźników płynności finansowej (w szczególności te, które są niższe niż wartości referencyjne), opóźnienia w spłacie wszelkich pożyczek oraz stale zwiększające się zapotrzebowanie podmiotu na kredyty, mimo że nie są realizowane żadne projekty inwestycyjne. Negatywny wpływ może mieć także sprzedaż aktywów trwałych i obrotowych, w tym zapasów po cenach niższych niż rynkowe (Bednarski 1999, s. 168).

W rozważaniach związanych $\mathrm{z}$ bankructwem i upadłością przedsiębiorstw należy wskazać przyczyny wewnątrzorganizacyjne, które mogą znacznie przyczynić się do pogorszenia funkcjonowania danego przedsiębiorstwa. Bardzo groźne mogą być powstające konflikty pomiędzy pracownikami oraz zmniejszająca się wydajność pracy. Również symptomy organizacyjne mogą doprowadzić do powstania oraz pogłębienia się kryzysu danego podmiotu. Wskazuje się, iż do głównych symptomów organizacyjnych zalicza się zwiększoną biurokrację, brak szkoleń czy długi proces decyzyjny w przedsiębiorstwie. Te, jak i reszta wskazanych symptomów, mogą doprowadzić do upadłości, a nawet bankructwa (Zelek i Gwarek 2000, s. 53).

Wczesne dostrzeżenie symptomów upadłości i bankructwa może umożliwić podjęcie działań naprawczych w odpowiednim czasie. Podmioty gospodarcze zapewniają zatrudnienie i są płatnikami podatków, dlatego przywrócenie przedsiębiorstwom zdolności do kontynuowania prowadzonej działalności jest szczególnie istotne z punktu widzenia gospodarki (Kopczyński 2016, s. 99).

\section{Proces upadłości przedsiębiorstw}

$\mathrm{Na}$ funkcjonowanie przedsiębiorstw w gospodarce mają wpływ różne czynniki wewnętrzne oraz zewnętrzne. W szczególności takie czynniki jak spadek ilości inwestycji, finansowanie kredytami krótkoterminowymi, a także zmniejszające się obroty finansowe oraz udział $\mathrm{w}$ danym rynku mogą powodować zagrożenie dla podmiotów gospodarczych. W literaturze przedmiotu wskazuje się cztery rodzaje faz powstającego kryzysu, które w ostateczności mogą spowodować upadłość danego podmiotu działającego na rynku (Antonowicz 2017, s. 56-70). Pierwsza faza zobrazowana jest w postaci odchyleń, które mogą pojawiać się w różnych

odstępach czasu. Zazwyczaj sporadycznie pojawiające się odchylenia nie mają zasadniczego wpływu na prawidłowe funkcjonowanie przedsiębiorstwa. Gdy nie zostaną one zauważone i skorygowane, to konsekwencją tego może być pojawienie się fazy drugiej, która wywiera wpływ na zmiany w działaniu danego przedsiębiorstwa, a następnie pogorszenie się jego sytuacji ekonomiczno-finansowej. Jeśli zarządzający nie podejmie działań naprawczych i nie wykorzysta posiadanych przez jednostkę zasobów, to nastąpi faza trzecia. $\mathrm{W}$ tej fazie przedsiębiorstwo 
osiąga coraz mniejsze przychody ze sprzedaży, ponadto znacznie zwiększają się koszty działalności. To okres zmniejszania się udziałów w rynku danego podmiotu gospodarczego. Ostatnią fazą jest bankructwo przedsiębiorstwa spowodowane nieusunięciem powstałych wcześniej zagrożeń (Balina i Bąk 2016, s. 68-69).

W celu przeciwdziałania upadłości zarządzający przedsiębiorstwem powinni zwracać szczególną uwagę na wszelkie błędne działania, które mogą skutkować niewypłacalnością podmiotu gospodarczego. Mniejsza liczba odbiorców może doprowadzić do pogorszenia rentowności jednostki. Dużym zagrożeniem może być utrata płynności finansowej przez dane przedsiębiorstwo. Jeśli przedsiębiorstwo przestanie regulować swoje zobowiązania w wyznaczonym terminie, mogą powstać tzw. zatory płatnicze. Kryzys płynności finansowej może być spowodowany m.in. zmniejszaniem wartości aktywów obrotowych, zbyt wysokimi zobowiązaniami krótkoterminowymi czy odzyskaniem należności krótkoterminowych. Konsekwencją utrzymującej się niekorzystnej sytuacji finansowej może być upadłość przedsiębiorstwa. Postępowanie upadłościowe jest wszczynane przez sąd na wniosek władz podmiotu lub jego wierzycieli. Należy jednak pamiętać, że upadłość jest procesem długotrwałym (Balina i Bąk 2016, s. 71).

\section{Predykcja upadłości - problem badawczy}

Upadłość przedsiębiorstwa jest złożonym procesem. W związku z tym zaproponowano specjalne narzędzia, które mają na celu określenie jak największego prawdopodobieństwa upadłości przedsiębiorstw. Takimi narzędziami są modele predykcji upadłości. Ich zadaniem jest zaalarmowanie o pogarszającej się sytuacji ekonomiczno-finansowej danego podmiotu gospodarczego. W literaturze przedmiotu istnieją dwa podejścia, które pomagają w szybszym przewidywaniu upadłości przedsiębiorstw. Pierwsze podejście ma charakter probabilistyczny. Predykcje upadłości określa się za pomocą statystycznych modeli logitowych, a także wielowymiarowej analizy dyskryminacyjnej. Drugie podejście ma charakter iteracyjny i jest związane z wykorzystaniem sztucznej inteligencji. Ponadto badacze Pociecha, Pawełek, Baryła oraz Augustyn wskazują na zastosowanie klasycznych metod, które są tworzone na podstawie analiz sprawozdań finansowych konkretnego przedsiębiorstwa (Pociecha i in. 2014, s. 12-13). W oparciu o rachunek zysków i strat, bilans oraz rachunek przepływów pieniężnych oblicza się wartości wskaźników rentowności, płynności, obrotowości, wartości rynkowej oraz zadłużenia. Na ich podstawie można określić sytuację finansową przedsiębiorstwa (Pociecha i in. 2014, s. 13). W ciągu ostatnich 40 lat przeprowadzono wiele badań, czego skutkiem było stworzenie różnych typów modeli prognozowania upadłości. Coraz częściej do predykcji upadłości stosuje się drzewa klasyfikacyjne (Pierzchalska 2014, s. 38). 
Stworzenie uniwersalnego modelu predykcji upadłości przedsiębiorstw nie jest proste, gdyż pojęcie upadłości jest złożone, a prawo upadłościowe może różnić się $\mathrm{w}$ różnych krajach. Ponadto istnieje problem z wiarygodnością danych prezentowanych w sprawozdaniach finansowych. Aktualnie oprócz danych finansowych uwzględnia się także pozafinansowe dane, np. strukturę branży, w jakiej funkcjonuje podmiot gospodarczy, czy współczynniki finansowe, których wartości nie zawsze są stabilne. Kolejną trudnością może być stworzenie odpowiedniej, reprezentatywnej próby spośród upadających podmiotów gospodarczych. Należy też zwrócić uwagę na wybór właściwych zmiennych objaśniających. Nie istnieją bowiem ogólnodostępne zasady określające sposób wprowadzania danych do modelu (Pociecha 2007).

W przypadku gdy występuje problem związany z odpowiednią klasyfikacją zbiorów, które mają odmienne cechy, stosuje się analizę dyskryminacyjną. Ma ona na celu sklasyfikowanie obiektów na podstawie różnych zmiennych. Zmienną objaśnianą uznaje się jako zmienną jakościową. W powyższej metodzie jest stosowana liniowa funkcja dyskryminacyjna, którą przedstawia się w postaci wzoru:

$$
Z=a_{0}+a_{1} X_{1}+a_{2} X_{2}+\ldots+a_{k} X_{k}
$$

gdzie:

Z - zmienna objaśniana (obliczana na podstawie sprawozdań finansowych),

$a_{0}$ - stała,

$a_{i}$ - współczynniki dyskryminacyjne, $i=1,2, \ldots, k$,

$X_{i}$ - zmienne objaśniające, $i=1,2, \ldots, k$.

Istnieje możliwość zakwalifikowania obiektu za pomocą porównania uzyskanej wartości danej funkcji z określoną przez twórców modelu wartością graniczną. W analizie dyskryminacyjnej, na podstawie określonego miernika, ocenia się sytuację finansową przedsiębiorstwa. Jak podaje Tłuczak, na terenie Polski będą miały zastosowanie wyłącznie polskie modele predykcji bankructwa, gdyż zagraniczne byłyby zbyt obciążone błędem predykcji (Tłuczak 2013, s. 425), co wiąże się z odmiennością warunków makroekonomicznych w różnych krajach. Zastosowanie zagranicznych modeli predykcji upadłości dla polskich przedsiębiorstw może dostarczyć niewiarygodne wyniki (Kitowski 2018, s. 52).

W rozważaniach związanych z predykcją upadłości należy wspomnieć o najważniejszych naukowcach, którzy zapoczątkowali badania nad tym zjawiskiem. W 1966 r. Beaver opracował jednowymiarowy model predykcji upadłości (Beaver 1966). W swoich badaniach ujął 79 przedsiębiorstw o dobrej sytuacji finansowej oraz taką samą liczbę podmiotów mających problemy z regulowaniem swoich zobowiązań w wyznaczonych terminach. Wyniki jego badań wykazały, że najodpowiedniejszym predyktorem ryzyka związanego z upadłością przedsiębiorstw jest relacja 
cash flow (dochód netto + amortyzacja) do zobowiązań ogółem (Pociecha i in. 2014, s. 16). Kolejnym badaczem był Altman, który dwa lata później przedstawił swój model analizy dyskryminacyjnej (Altman 1968), natomiast w latach 80. XX wieku Ohlson zastosował warunkową analizę logitową (Ohlson 1980, s. 110-130).

Model prognozowania upadłości autorstwa Altmana jest jednym z najbardziej znanych na świecie. Autor ten podzielił przedsiębiorstwa amerykańskie na bankrutów oraz nie bankrutów. Badana grupa liczyła 66 przedsiębiorstw, z czego połowa stała się bankrutami w latach 1946-1965, z kolei 33 wybrane przedsiębiorstwa nie zbankrutowały w tym okresie. Model Altmana często jest używany do określania zagrożenia ze względu na wysoką skuteczność oraz dokładność. Funkcja dyskryminacyjna Altmana zwana „Z-score model” ma następujący wzór (Altman 1993, s. 186-187):

$$
Z=1,2 X_{2}+1,4 X_{15}+3,3 X_{12}+0,6 X_{5}+0,999 X_{7}
$$

gdzie:

$X_{2}$ - kapitał pracujący/majątek ogółem,

$X_{15}$ - zysk zatrzymany/majątek ogółem,

$X_{12}$ - zysk przed opodatkowaniem/majątek ogółem,

$X_{5}$ - całkowity kapitał rynkowy (wartość rynkowa kapitału akcyjnego)/wartość księgowa zadłużenia (całkowite kredyty),

$X_{7}$ - przychody ze sprzedaży/majątek ogółem.

Jak wskazuje Arroyave, najbardziej przydatnym wskaźnikiem okazał się $X_{2}$ który przedstawia charakterystykę płynności oraz wielkości przedsiębiorstwa. To miara kapitału pracującego netto przedsiębiorstwa w stosunku do całkowitej kapitalizacji. Należy również zwrócić uwagę na znaczenie wskaźnika $X_{5}$ wskazującego utratę wartości aktywów przed uwzględnieniem posiadanych zobowiązań. Każdy z tych wskaźników jest istotny do przewidzenia zagrożenia upadłością danego przedsiębiorstwa (Arroyave 2018, s. 276). Na podstawie modelu Altmana powstało wiele późniejszych modeli predykcji upadłości przedsiębiorstw.

\section{Polskie modele prognozowania upadłości przedsiębiorstw}

Problem upadłości przedsiębiorstw nie jest nowy. Wielu badaczy na całym świecie (w tym w Polsce) zajęło się problematyką predykcji upadłości przedsiębiorstw. Stworzyli oni m.in. specjalne modele prognozowania, które najbardziej odwzorowują sytuację w gospodarce polskiej (Balina i Bąk 2016, s. 98-99).

Pierwszym przedstawionym modelem służących do prognozowania upadłości danego przedsiębiorstwa jest model Hadasik (Hadasik 1998). Stworzyła ona 
9 modeli, które mają na celu wczesne zasygnalizowanie ryzyka związanego z możliwością upadłości danego przedsiębiorstwa. Modele te powstały przy użyciu liniowej funkcji dyskryminacyjnej. W badaniu wykorzystano przedsiębiorstwa, które charakteryzują się różnorodną strukturą własności, takie jak spółki akcyjne, spółki niepubliczne i publiczne bądź przedsiębiorstwa prywatne i państwowe. Jeden z modeli autorki został zaprezentowany poniżej (Hadasik 1998, s. 130-175):

$$
\begin{gathered}
Z_{H A}=2,36261+0,365425 X_{1}-0,765526 X_{2}-2,40435 X_{3}+1,59079 X_{4}+ \\
+0,00230258 X_{5}-0,0127826 X_{6}
\end{gathered}
$$

gdzie:

$X_{1}$ - aktywa bieżące/zobowiązania bieżące,

$X_{2}$ - (aktywa bieżące - zapasy)/zobowiązania bieżące,

$X_{3}$ - zobowiązania ogółem/ aktywa ogółem,

$X_{4}$ - (aktywa bieżące - zobowiązania krótkoterminowe)/pasywa ogółem,

$X_{5}$ - suma należności/przychody ze sprzedaży,

$X_{6}-$ zapasy/przychody ze sprzedaży.

W celu określenia, czy dane przedsiębiorstwo jest zagrożone upadłością, należy uzyskaną wartość równania porównać $\mathrm{z}$ wartością graniczną. W przypadku modelu Hadasik wartość graniczna wynosi 0 .

Kolejnym modelem służącym do predykcji upadłości jest model stworzony przez Hołdę. Model ten opiera się na danych finansowych przedsiębiorstw, których działalność dotyczy m.in. handlu hurtowego bądź detalicznego, hotelarstwa, transportu, obsługi nieruchomości, budownictwa, mechaniki pojazdowej czy magazynowania. W badaniu brało udział 80 różnych przedsiębiorstw, z czego 40 było zagrożonych upadłością, a 40 charakteryzowała stabilna sytuacja finansowa. Okres badania opierał się na latach 1993-1996. Twórca modelu zaproponował wskaźniki, które były obliczane dla podmiotów już uznanych za bankrutów, na rok przed oficjalnym ogłoszeniem upadłości. W początkowej fazie badań wskazano dwadzieścia osiem wskaźników, a następnie przyporządkowano je odpowiednio do czterech grup takich jak wskaźniki płynności, obrotowości, stopnia zadłużenia oraz rentowności. Ostatecznie Hołda wybrał pięć wskaźników i stworzył funkcję dyskryminacyjną, która się na nich opierała. Funkcję te wskazano poniżej (Hołda 2001, s. 310):

$$
Z_{H}=0,681 X_{1}-0,0196 X_{2}+0,00969 X_{3}+0,000672 X_{4}+0,157 X_{5}+0,605
$$

gdzie:

$X_{1}$ - aktywa obrotowe/zobowiązania krótkoterminowe,

$X_{2}$ - zobowiązania ogółem/aktywa ogółem, 
$X_{3}$ - wynik finansowy netto/przeciętny stan aktywów ogółem,

$X_{4}$ - przeciętny stan zobowiązań krótkoterminowych/(koszty działalności operacyjnej - pozostałe koszty operacyjne),

$X_{5}$ - przychody ogółem/przeciętny stan aktywów ogółem.

W prowadzonych przez Hołdę badaniach skuteczność jego modelu wyniosła $92,5 \%$. W opisywanym modelu wartość graniczna wyniosła $-0,3$. Jeśli wartość funkcji wyniosła $-0,3$ bądź była mniejsza to dane przedsiębiorstwo w ciągu najbliższego roku powinno upaść. Natomiast, gdy wartość funkcji była równa lub większa od 0,1, oznaczało to, że badane przedsiębiorstwo nie powinno być zagrożone upadłością. Jednak nie zawsze model rozstrzyga czy podmiot gospodarczy jest zagrożony. Taka sytuacja występuje w przypadku, gdy wartość funkcji krytycznej znajduje się w przedziale od -0,3 do 0,1 (Hołda 2001, s. 310).

Kolejnym modelem, który należy rozważyć w badaniu predykcji upadłości jest model stworzy przez Hamrola, Czajkę i Piechockiego. Model ten nazwany jest poznańskim (Hamrol, Czajka i Piechocki 2004, s. 35-38). Przedmiotem badań tego zespołu były rachunki zysków i strat oraz bilanse spółek. Zbadano sto przedsiębiorstw, które swoją działalność prowadziły na terenie Polski. Przeanalizowano wszystkie sprawozdania finansowe z lat 1999-2002. Składowymi próby było 50 spółek działających prawidłowo, o dobrej kondycji finansowej oraz 50 przedsiębiorstw, które miały status bankruta. Badacze na podstawie badań stworzyli liniową, wielowymiarową analizę dyskryminacyjną. Powstała funkcja ma następującą postać (Hamrol, Czajka i Piechocki 2004, s. 35-38):

$$
Z_{H C P}=3,562 X_{1}+1,588 X_{2}+4,288 X_{3}+6,719 X_{4}-2,368
$$

gdzie:

$X_{1}$ - wynik finansowy netto/majątek całkowity,

$X_{2}$ - (majątek obrotowy - zapasy)/zobowiązania krótkoterminowe,

$X_{3}$ - kapitał stały/majątek całkowity,

$X_{4}-$ wynik ze sprzedaży/przychody ze sprzedaży.

W przedstawionym modelu wartość graniczna wynosi 0 . W przypadku, gdy uzyskana wartość funkcji jest równa bądź większa od 0 , to dane przedsiębiorstwo nie powinno obawiać się upadłości. Zagrożenie upadłością jest możliwe, gdy wartość obliczonej funkcji jest ujemna. Według autorów tego modelu jest on wysoce skuteczny (Balina i Bąk 2016, s. 113).

Ostatnim modelem przedstawionym w opracowaniu jest model Prusaka (Prusak 2005). Autor ten w oparciu o swoje badania stworzył cztery modele informujące o zagrożeniu upadłością podmiotu gospodarczego. W początkowej fazie opracowano dwa modele, w których próbą było 80 przedsiębiorstw, w tym 
połowa z nich upadła. Model ten został opracowany na podstawie sprawozdań finansowych z pięciu lat (1998-2002). Badacz w rozważaniach użył liniowej, wielowymiarowej analizy dyskryminacyjnej. Funkcję tę przedstawiono poniżej (Prusak 2005):

$$
Z_{\mathrm{B} 1}=6,5245 X_{1}+0,1480 X_{2}+0,4061 X_{3}+2,1754 X_{4}-1,5685
$$

gdzie:

$X_{1}$ - wynik z działalności operacyjnej/średnia wartość sumy bilansowej, $X_{2}$ - koszty operacyjne/średnia wartość zobowiązań krótkoterminowych, $X_{3}$ - aktywa obrotowe/zobowiązania krótkoterminowe, $X_{4}$ - wynik z działalności operacyjnej/przychody netto ze sprzedaży.

Aby prawidłowo ocenić poziom zagrożenia upadłością należy uzyskaną wartość funkcji porównać z wartościami brzegowymi. Są one następujące (Balina i Bąk 2016):

- $\mathrm{Z}_{\mathrm{B} 1}>0,65$ oznacza, że przedsiębiorstwo nie jest zagrożone upadłością,

- $\mathrm{Z}_{\mathrm{B} 1}<-0,13$ oznacza, że istnieje ryzyko upadłości przedsiębiorstwa w ciągu jednego roku,

- $\mathrm{Z}_{\mathrm{B} 1}$ znajduje się $\mathrm{w}$ przedziale $<-0,13 ; 0,65>$ oznacza, że nie można jednoznacznie ocenić ryzyka upadłości.

Autor ten zaproponował też drugi model, którego funkcja ma następujący wzór:

$$
Z_{\mathrm{B} 2}=1,4383 X_{1}+0,1878 X_{2}+5,02291 X_{3}-1,8713
$$

gdzie:

$X_{1}-$ (wynik netto + amortyzacja)/zobowiązania ogółem,

$X_{2}$ - koszty operacyjne/wartość średnia zobowiązań krótkoterminowych,

$X_{3}$ - wynik ze sprzedaży/wartość średnia sumy bilansowej.

Obliczoną wartość funkcji interpretuje się za pomocą poniższych kryteriów:

- $\mathrm{Z}_{\mathrm{B} 2}>0,2$ oznacza, że dane przedsiębiorstwo nie jest zagrożone upadłością,

- $\mathrm{Z}_{\mathrm{B} 2}$ należy do przedziału $<-0,7 ; 0,2>$ oznacza, że nie jest możliwa ocena przedsiębiorstwa pod względem ryzyka upadłości,

- $\mathrm{Z}_{\mathrm{B} 2}<-0,7$ oznacza, że istnieje duże prawdopodobieństwo upadłości przedsiębiorstwa w ciągu dwóch lat (Balina i Bąk 2016, s.113-115). 
Trzeci model autorstwa Prusaka jest oparty na liniowej, wielowymiarowej analizie dyskryminacyjnej. Powstał on na podstawie analizy 140 przedsiębiorstw, spośród których połowa funkcjonowała prawidłowo. Jego wzór zaprezentowano poniżej:

$$
Z_{\mathrm{B} 3}=6,9973 X_{1}+0,1191 X_{2}+0,1932 X_{3}-1,1760
$$

gdzie:

$X_{1}$ - wynik ze sprzedaży/wartość sumy bilansowej,

$X_{2}$ - koszty operacyjne/średnia wartość zobowiązań krótkoterminowych,

$X_{3}$ - aktywa obrotowe/zobowiązania krótkoterminowe.

Wartość graniczna powyższej funkcji wynosi 0 . Jeśli osiągnięty wynik będzie równy 0 lub ujemny, to istnieje wysokie prawdopodobieństwo, że przedsiębiorstwo upadnie w ciągu najbliższego roku. W przypadku gdy wartość funkcji okaże się dodatnia, przedsiębiorstwo nie będzie zagrożone upadłością.

Czwartą funkcję stworzoną przez Prusaka przedstawia poniższy wzór:

$$
Z_{\mathrm{B} 4}=3,7657 X_{1}+0,1049 X_{2}-1,6765 X_{3}+3,5230 X_{4}-0,3758
$$

gdzie:

$X_{1}$ - wynik ze sprzedaży/wartość średnia sumy bilansowej,

$X_{2}$ - koszty operacyjne/wartość średnia zobowiązań krótkoterminowych,

$X_{3}$ - zobowiązania krótkoterminowe/suma bilansowa,

$X_{4}$ - wynik z działalności operacyjnej/wartość średnia sumy bilansowej.

W przypadku tego modelu wartość graniczna również jest równa 0 . Ujemna wartość funkcji dyskryminacyjnej oznacza, że przedsiębiorstwo powinno w ciągu najbliższego roku upaść. Wszystkie opisane modele Prusaka cechowała wysoka skuteczność - blisko 92\% (Prusak 2005).

\section{Monnari Trade S.A. - studium przypadku}

Monnari Trade S.A. to łódzka spółka, która zaczęła funkcjonować w 1988 r. Początkowo była to spółka cywilna, lecz w 2000 r. zmieniono jej formę prawną na spółkę akcyjną „Monnari Trade”. Podstawowa działalność przedsiębiorstwa opiera się na projektowaniu, szyciu i sprzedaży odzieży damskiej. Każdego roku przedsiębiorstwo stawało się coraz bardziej rozpoznawalne na rynku polskim. Rok 2006 był debiutem Monnari Trade S.A. na Giełdzie Papierów Wartościowych w Warszawie S.A. (Monnari Trade SA 2010, s. 4-5). 
Problemy finansowe spółki zaczęły się w 2009 r. w czasie światowego kryzysu finansowego. Z powodu dekoniunktury gospodarczej przedsiębiorstwo utraciło możliwość pełnej kontroli spółek od niej zależnych, skutkiem czego było wniesienie w maju 2009 r. wniosku do sądu w celu uznania upadłości układowej. Wniosek ten został złożony przez ówczesny zarząd Monnari Trade. Sąd ogłosił upadłość z likwidacją posiadanego przez spółkę majątku. Innym powodem jej kłopotów finansowych było przeinwestowanie oraz posiadanie nierentownych salonów na terenie Polski. Kolejnym krokiem było przekształcenie upadłości na upadłość układową. Zarząd podjął działania, które przyczyniły się do poprawienia sytuacji firmy, a spółka zaczęła przynosić zyski. Powstała nowa, innowacyjna strategia przedsiębiorstwa oraz przeprowadzono negocjacje $\mathrm{z}$ wierzycielami. Zgłoszono nowy wniosek do sądu, czego skutkiem było zakończenie toczącego się postępowania upadłościowego (Monnari Trade SA 2010, s. 4-5).

W artykule wykorzystano wybrane polskie modele predykcji upadłości przedsiębiorstw dla spółki Monnari Trade S.A. w celu wskazania, czy badane przedsiębiorstwo było zagrożone upadłością. Zastosowano polskie modele, ponieważ modele zagraniczne byłyby zbyt obciążone błędem predykcji. Polskie modele predykcji upadłości mają na celu zaalarmować inwestorów i właścicieli o złej kondycji finansowej przedsiębiorstwa. Wartości modeli zostały oszacowane dla lat 2008-2014. Okres badawczy wybrano w celu zobrazowania sytuacji ekonomiczno-finansowej przedsiębiorstwa przed wszczęciem postępowania upadłościowego oraz w okresie po zażegnaniu kryzysu w spółce. Obliczenia opierają się na analizie ilościowej danych zebranych z bilansu oraz rachunku zysków i strat. Przyjęto roczne dane bilansowe. Użyte $w$ badaniu dane pochodzą $z$ bazy danych EMIS - Standard MSSF dla przedsiębiorstw niefinansowych.

W tabeli 1 zaprezentowano wartości modelu Hadasik dla Monnari Trade S.A. w latach 2008-2014.

Tabela 1. Wartości modelu Hadasik dla Monnari Trade S.A. w latach 2008-2014

\begin{tabular}{|c|c|}
\hline Model & Wartość modelu \\
\hline$Z_{\text {HA 2008 }}$ & 0,82 \\
\hline$Z_{\text {HA 2009 }}$ & $-0,23$ \\
\hline$Z_{\text {HA 2010 }}$ & 1,29 \\
\hline$Z_{\text {HA 2011 }}$ & 1,44 \\
\hline$Z_{\text {HA 2012 }}$ & 1,78 \\
\hline$Z_{\text {HA 2013 }}$ & 1,68 \\
\hline$Z_{\text {HA 2014 }}$ & 1,72 \\
\hline
\end{tabular}

Źródło: obliczenia własne na podstawie Standard MSSF dla Niefinansowych Przedsiębiorstw (EMIS) (data dostępu: 12.02.2021). 
Na podstawie powyższych wyników można wywnioskować, że przedsiębiorstwo Monnari Trade S.A. powinno upaść do 2010 r., bowiem w 2009 r. wartość modelu była ujemna. Skutkiem takiej sytuacji były zwiększające się wartości zobowiązań bieżących przedsiębiorstwa.

W tabeli 2 przedstawiono wartości modelu Hołdy dla Monnari Trade S.A. w latach 2008-2014.

Tabela 2. Wartości modelu Hołdy dla Monnari Trade S.A. w latach 2008-2014

\begin{tabular}{|c|c|}
\hline Model & Wartość modelu \\
\hline$Z_{\mathrm{H} 2008}$ & 1,46 \\
\hline$Z_{\mathrm{H} 2009}$ & 1,08 \\
\hline$Z_{\mathrm{H} 210}$ & 2,33 \\
\hline$Z_{\mathrm{H} 2011}$ & 4,51 \\
\hline$Z_{\mathrm{H} 2012}$ & 2,49 \\
\hline$Z_{\mathrm{H} 2013}$ & 5,08 \\
\hline$Z_{\mathrm{H} 2014}$ & 5,71 \\
\hline
\end{tabular}

Źródło: obliczenia własne na podstawie Standard MSSF dla Niefinansowych Przedsiębiorstw (EMIS) (data dostępu: 12.02.2021).

Na podstawie oszacowań dla modelu Hołdy można zauważyć, że w latach 2008-2014 nie istniało zagrożenie upadłością dla Monnari Trade S.A., choć wartość modelu prognozowania bankructwa w 2009 r. była najniższa spośród lat ujętych w badaniu.

W tabeli 3 zaprezentowano wartości modelu autorska Hamrola, Czajki i Piechockiego w latach 2008-2014.

Tabela 3. Wartości modelu poznańskiego dla przedsiębiorstwa Monnari Trade S.A. w latach 20082014

\begin{tabular}{|c|c|}
\hline Model & Wartość modelu \\
\hline$Z_{\text {HCP 2008 }}$ & 3,75 \\
\hline$Z_{\mathrm{HCP} \mathrm{2009}}$ & $-4,07$ \\
\hline$Z_{\mathrm{HCP} \mathrm{2010}}$ & 8,75 \\
\hline$Z_{\mathrm{HCP} \mathrm{2011}}$ & 10,78 \\
\hline$Z_{\text {HCP 2012 }}$ & 7,32 \\
\hline$Z_{\mathrm{HCP} \mathrm{2013}}$ & 13,50 \\
\hline$Z_{\mathrm{HCP} \mathrm{2014}}$ & 14,87 \\
\hline
\end{tabular}

Źródło: obliczenia własne na podstawie Standard MSSF dla Niefinansowych Przedsiębiorstw (EMIS) (data dostępu: 12.02.2021). 
Dla modelu autorstwa Hamrola, Czajki oraz Piechockiego wartość graniczna wynosiła 0 . Na podstawie danych zawartych w tabeli 3 można zaobserwować, iż w 2009 r. osiągnięta wartość modelu była najniższa w badanym okresie. Wartość funkcji była znacznie niższa od wartości krytycznej i wynosiła -4,07. Oznaczałoby to, że przedsiębiorstwo Monnari Trade S.A. powinno upaść do 2010 r. W tym okresie wynik finansowy netto badanego przedsiębiorstwa był znacznie niższy niż w innych latach.

W tabeli 4 zobrazowano wartości modelu Prusaka dla Monnari Trade S.A. w latach 2008-2014.

Tabela 4. Wartości modelu Prusaka dla Monnari Trade S.A. w latach 2008-2014

\begin{tabular}{|c|c|}
\hline Model & Wartość modelu \\
\hline$Z_{\text {B1 2008 }}$ & $-0,72$ \\
\hline$Z_{\text {B1 2009 }}$ & $-5,91$ \\
\hline$Z_{\text {B1 2010 }}$ & $-0,53$ \\
\hline$Z_{\text {B1 2011 }}$ & 0,27 \\
\hline$Z_{\text {B1 2012 }}$ & 0,08 \\
\hline$Z_{\text {B1 2013 }}$ & 2,23 \\
\hline$Z_{\text {B1 2014 }}$ & 3,18 \\
\hline
\end{tabular}

Źródło: obliczenia własne na podstawie Standard MSSF dla Niefinansowych Przedsiębiorstw (EMIS) (data dostępu: 12.02.2021).

Ostatnim przedstawionym $\mathrm{w}$ opracowaniu modelem jest ten zaproponowany przez Prusaka. W przypadku tego modelu wartość krytyczna wynosiła $-0,13$. Na podstawie danych zawartych w tabeli 4 można zauważyć, że w latach 2008-2010 wartość modelu była ujemna. Najniższa wartość została osiągnięta w 2009 r., wartość ta była kilkakrotnie niższa od punktu granicznego. Wskazywałoby to, że przedsiębiorstwo Monnari Trade S.A. powinno upaść. Najważniejszymi z powodów tego zjawisko były m.in. zwiększające się każdego roku zobowiązania krótkoterminowe przedsiębiorstwa oraz ujemne wartości kapitału własnego ogółem.

\section{Podsumowanie}

Prawidłowe funkcjonowanie przedsiębiorstw w gospodarce jest zależne od wielu czynników. Pogarszające się wyniki finansowe przedsiębiorstwa powinny wzbudzić niepokój wśród zarządzających, gdyż może to doprowadzić do zaburzeń związanych $\mathrm{z}$ regulowaniem powstałych zobowiązań w wyznaczonym przez wierzycieli terminie. Jeśli nie zostanie wprowadzony odpowiedni program 
naprawczy, może to skutkować brakiem płynności finansowej przedsiębiorstwa, a w ostateczności postępowaniem upadłościowym.

Upadłość przedsiębiorstw nie jest nowym problem pojawiającym się w gospodarce światowej. W literaturze przedmiotu istnieją modele predykcji upadłości, które zostały opracowane przez naukowców całego świata. Mają one na celu zaalarmować o pojawiającym się zagrożeniu upadłości danego podmiotu.

W opracowaniu wskazano polskie modele predykcji upadłości, a następnie zbadano ich użyteczność w procesie predykcji polskiej spółki Monnari Trade S.A. $\mathrm{Na}$ podstawie przeprowadzonego badania uzyskano wyniki niejednoznaczne. Model stworzony przez Hadasik był najbardziej wiarygodny - prawidłowo dokonano analizy przedsiębiorstwa i wskazano, iż Monnari Trade S.A. jest zagrożone upadłością. Wartości modelu poznańskiego również jednoznacznie wskazały na to, że spółka nie działa prawidłowo i do 2010 r. powinna ogłosić upadłość. Na podstawie modelu Prusaka można dostrzec, że wartość modelu w 2009 r. była kilkakrotnie niższa od wartości granicznej, co oznacza silnie pogarszającą się sytuację ekonomiczno-finansową przedsiębiorstwa Monnari Trade S.A. Skutkiem tego powinna być upadłość podmiotu do 2010 r.. Najmniej wiarygodne wnioski zostały zaprezentowane w modelu autorstwa Hołdy. W przypadku tego modelu można zaobserwować, że $\mathrm{w}$ żadnym $\mathrm{z}$ badanych lat przedsiębiorstwo nie było zagrożone upadłością.

$\mathrm{Na}$ podstawie opracowanych modeli predykcji upadłości przedsiębiorstw polskich badaczy można potwierdzić słuszność hipotezy. Większość przedstawionych modeli prawidłowo oceniła sytuację ekonomiczną przedsiębiorstwa Monnari Trade S.A., korzystając z analizy ilościowej danych, które zostały zebrane na podstawie rachunku zysków i strat oraz bilansu badanego podmiotu gospodarczego. Jedynie model upadłości Hołdy okazał się nieskuteczny, co mogło doprowadzić do niezauważenia pojawiającego się zagrożenia przez kadrę kierowniczą spółki. Tekst ma charakter pilotażowy i służy on pogłębieniu wiedzy na temat zdolności prognozowania upadłości przedsiębiorstw w oparciu o modele dyskryminacyjne.

\section{Bibliografia}

Abdali M., Abbas A. (2015), Companies Bankruptcy Prediction by Using Altman Models amd Comparing Them, „Research Journal of Finance and Accounting", t. 6, nr 14.

Altman E. (1993), Corporate financial distress and bankruptcy: a complete guide to predicting, avoiding distress and profiting from bankruptcy, New York.

Altman I.E. (1968), Financial Ratios, Discriminant Analysis and the Prediction of Corporate Bankruptcy, „Journal of Finance”, t. 23, nr 4. https://doi.org/ 10.1111/j.1540-6261.1968.tb00843.x 
Antonowicz P. (2015), Bankructwa i upadtości przedsiębiorstw. Teoria-praktyka gospodarcza - studia regionalne, Wydawnictwo Uniwersytetu Gdańskiego, Gdańsk.

Arroyave J. (2018), A comparative analysis of the effectiveness of corporate bankruptcy prediction models based on financial ratios: Evidence from Columbia, „Journal of International Studies”, t. 11, nr 1. https://doi.org/10.14254/2071$8330.2018 / 11-1 / 21$

Balina R., Bąk M.J. (2016), Analiza dyskryminacyjna jako metoda predykcji bankructwa przedsiębiorstw z uwzględnieniem aspektów branżowych, Waleńczów.

Bauer K. (2010), Kryzys finansowy a restrukturyzacja przedsiębiorstw w stanie upadłości, „Prace Komisji Geografii Polskiego Towarzystwa Geograficznego, Procesy transformacji przemysłu i usług w regionalnych i krajowych układach przestrzennych", nr 15, Warszawa-Kraków. https://doi. org/10.24917/20801653.15.18

Beaver W. (1966), Financial ratios as predictors of failure, „Journal of Accounting Research (Supplement)", t. 4, nr 3. https://doi.org/10.2307/2490171

Beaver W. (1968), Alternative Accounting Measures as Predictors of Failure, „Accounting Review”, nr 1.

Bednarski L. (1999), Symptomy i ocena zagrożenia sytuacji finansowej przedsiębiorstwa", Wydawnictwo Pieniądze i Więź, Sopot.

Buczyńska T. (2007), Mikroekonomia, Warszawa-Lódź.

Hadasik D. (1998), Upadłość przedsiębiorstw w Polsce i metody jej prognozowania, Akademia Ekonomiczna w Poznaniu, „Zeszyty Naukowe”, seria II.

Hadasik D., Kowalski T. (1997), Transformacja makroekonomiczna a upadtość przedsiębiorstw, „Ruch Prawniczy, Ekonomiczny i Socjologiczny”, z. 1.

Hamrol M., Czajka B., Piechocki M. (2004), Upadtość przedsiębiorstwa - modele analizy dyskryminacyjnej, „Przegląd Organizacji”, nr 6. https://doi. org/10.33141/po.2004.06.09

Hołda A. (2001), Prognozowanie bankructwa jednostki w warunkach gospodarki polskiej z wykorzystaniem funkcji dyskryminacyjnej $Z H$, „Rachunkowość 2001", nr 5.

Kitowski J. (2018), Metody dyskryminacyjne oceny kondycji finansowej przedsiębiorstw - bariery wiarygodnego stosowania, „Annales Universitatis Mariae Curie-Skłodowska Lublin-Polonia", t. LII, nr 3.

Kopczyński P. (2016), Metody prognozowania upadłości wykorzystywane w praktyce przez polskie przedsiębiorstwa - wyniki badań ankietowych, „Zeszyty Teoretyczne Rachunkowości”, t. 89(145), Stowarzyszenie Księgowych w Polsce.

Korol T., Prusak B. (2014), Upadtość przedsiębiorstw a wykorzystanie sztucznej inteligencji, Warszawa. 
Mączyńska E., Zawadzki M. (2000), Modelowe i prognostyczne aspekty pomiaru zmian $w$ sytuacji przedsiębiorstw $w$ restrukturyzacji - analiza dyskryminacyjna, Warszawa.

Mączyńska E., Zawadzki M. (2006), Dyskryminacyjne modele predykcji upadłości przedsiębiorstw, „Ekonomista”, nr 2.

Ohlson J. (1980), Financial ratios and the probabilistic prediction of bankruptcy, „Journal of Accounting Research”, t. 18, nr 1.https://doi.org/10.2307/2490395

PARP (2017), Sektor MSP w Polsce i UE, Warszawa.

PARP (2020), Raport o stanie sektora matych $i$ średnich przedsiębiorstw w Polsce, Warszawa.

Pierzchalska W.B. (2014), Analiza finansowa oraz modele przewidywania upadtości jako narzędzie oceny kondycji finansowej przedsiębiorstwa, „Finanse i Prawo Finansowe", nr 1. https://doi.org/10.18778/2391-6478.1.1.04

Pociecha J. (2007), Problemy prognozowania bankructwa firmy metoda analizy dyskryminacyjnej, „Acta Universitatis Lodziensis. Folia Oeconomica”, nr 205.

Pociecha J., Pawełek B., Baryła M., Augustyn S. (2014), Statystyczne metody prognozowania bankructwa $w$ zmieniajacej się koniunkturze gospodarczej, Kraków.

Prawo upadłościowe i naprawcze z 28.02.2003 r., Dz.U. z 2003 r., nr 60, poz. 535. Prusak B. (2002), Upadlość - mit klęski czy szansa na odrodzenie, „Prace Naukowe Katedry Ekonomii i Zarządzania Przedsiębiorstwem”, red. H. Różańska, t. 1, Warszawa.

Prusak B. (2005), Nowoczesne metody prognozowania zagrożenia finansowego przedsiębiorstwa, Warszawa.

Raport Finansowy „Monnari Trade SA” (2010).

Standard MSSF dla Niefinansowych Przedsiębiorstw (EMIS) (data dostępu: 12.02.2021).

Sudoł S. (2006), Przedsiębiorstwo. Podstawy nauki o przedsiębiorstwie. Zarzqdzanie przedsiębiorstwem, Warszawa.

Tłuczak A. (2013), Zastosowanie dyskryminacyjnych modeli przewidywania bankructwa do oceny ryzyka upadłości przedsiębiorstw, „Zeszyty Naukowe Wyższej Szkoły Bankowej we Wrocławiu", nr 2(34).

Zakrzewski R., Chaber P. (2017), Sektor matych i średnich przedsiębiorstw w Polsce i Unii Europejskiej, PARP, Warszawa.

Zelek A., Gwarek A. (2000), Symptomy kryzysu organizacji, „Firma i Rynek”, nr 2. 


\section{Summary}

Prediction of bankruptcy of exterprises - the example of Monnari Trade S.A.

The article presents the phenomenon of enterprise bankruptcy. An enterprise is considered bankrupt when it does not have a sufficient amount of financial resources allowing for the repayments of its liabilities. There are numerous reasons for this phenomenon presented in the literature. One of them is the company's financial situation, which may result in a lack of solvency.

Any symptoms that indicate a worsening situation of the enterprise should be profoundly analyzed. Recognizing these symptoms early and implementing corrective actions can prevent a business from going bankrupt. Based on many years of research, special tools were created to determine the bankruptcy of a given entity - so-called "bankruptcy prediction models". The aim of the article is to use selected Polish models of bankruptcy prediction of enterprises in the process of forecasting bankruptcy of Monnari Trade S.A.

The analysis was made on the basis of data obtained from the EMIS database - Standard MSSF for non - financial enterprises. The function values were calculated using MS Excel. The research hypothesis is as follows: the bankruptcy forecasting models of Hadasik, Hołda, Prusak, Hamrol, Czajka and Piechocki are used to provide early warning about the risk of bankruptcy of the analyzed business entity. Based on the obtained values, the models' effectiveness was deeply investigated.

Keywords: prediction of bankruptcy, enterprises, discriminative models 